Article

\title{
Hmox1 Upregulation Is a Mutual Marker in Human Tumor Cells Exposed to Physical Plasma-Derived Oxidants
}

\author{
Sander Bekeschus *(D), Eric Freund, Kristian Wende, Rajesh Kumar Gandhirajan and \\ Anke Schmidt \\ ZIK plasmatis, Leibniz Institute for Plasma Science and Technology (INP), Felix-Hausdorff-Str. 2, \\ 17489 Greifswald, Germany; eric.freund@inp-greifswald.de (E.F.); kristian.wende@inp-greifswald.de (K.W.); \\ rajesh.gandhirajan@inp-greifswald.de (R.K.G.); anke.schmidt@inp-greifswald.de (A.S.) \\ * Correspondence: sander.bekeschus@inp-greifswald.de; Tel.: +49-3834-554-3948
}

Received: 28 September 2018; Accepted: 25 October 2018; Published: 27 October 2018

\begin{abstract}
Increasing numbers of cancer deaths worldwide demand for new treatment avenues. Cold physical plasma is a partially ionized gas expelling a variety of reactive oxygen and nitrogen species, which can be harnesses therapeutically. Plasmas and plasma-treated liquids have antitumor properties in vitro and in vivo. Yet, global response signatures to plasma treatment have not yet been identified. To this end, we screened eight human cancer cell lines to investigate effects of low-dose, tumor-static plasma-treated medium (PTM) on cellular activity, immune-modulatory properties, and transcriptional levels of 22 redox-related genes. With PTM, a moderate reduction of metabolic activity and modest modulation of chemokine/cytokine pattern and markers of immunogenic cell death was observed. Strikingly, the Nuclear factor (erythroid-derived 2)-like 2 (nrf2) target heme oxygenase 1 ( $h$ mox1) was upregulated in all cell lines $4 \mathrm{~h}$ post PTM-treatment. $n r f 2$ was not changed, but its baseline expression inversely and significantly correlated with hmox 1 expression after exposure to PTM. Besides awarding hmox1 a central role with plasma-derived oxidants, we present a transcriptional redox map of 22 targets and chemokine/cytokine secretion map of 13 targets across eight different human tumor cell lines of four tumor entities at baseline activity that are useful for future studies in this field.
\end{abstract}

Keywords: heme oxygenase 1; kINPen; plasma medicine; reactive oxygen and nitrogen species; RNS; ROS

\section{Introduction}

Cancer is the second leading cause of death worldwide [1]. Hence, global research efforts aim at better understanding cancer pathology and the discovery of new therapeutic avenues to combat disease. While there is a plethora of small molecules and biologicals being investigated for antitumor effects, research on a number of technological approaches supporting therapies or targeting cancer is carried as well. This includes studies using nanoparticles [2], photodynamic therapy [3], high hydrostatic pressure [4], acoustic treatment [5], hyperthermia [6], ionizing radiation combinational therapies [7], and cold-physical plasma-based approaches [8]. Cold physical plasma is a partially ionized gas that is generated at body temperature and composed of multiple effectors, such as electric fields, light radiation, ions and electrons, and reactive oxygen and nitrogen species (ROS/RNS) [9]. The later are hypothesized to be the main component responsible for antitumor effects observed with plasma treatment [10]. This includes the inactivation of tumor cells in vitro [11-13] and in vivo [14-16]. The use of plasma-treated liquids directly injected into tumors or used as lavage in peritoneal carcinomatosis 
has been motived in vivo as well [17-19]. Recently, first patients suffering from head and neck cancer benefited from plasma therapy in the palliative stage [20-22].

Despite many studies reporting on antitumor effects of cold physical plasma, molecular mechanism responsible for the effects observed are less investigated. However, common (bio-) markers that are associated with plasma treatment are missing. Along similar lines, there is an unmet need for the identification of markers for other types of therapies including ionizing radiation [23] and photodynamic therapy (PDT) [24]. Established markers would allow not only tracking, but also for quantifying the therapeutic efficacy of a given treatment.

Plasma treatment release ROS/RNS, and these are known to act in redox signaling pathways. A major pathway is that of the Nuclear factor (erythroid-derived 2)-like 2 ( $n r f 2$ ). $n r f 2$ signaling is important in many physiological and pathological conditions, including cancer [25]. Once released from Keap 1 under oxidative stress conditions, $n r f 2$ translocates to the nucleus where it binds phase II enzymes of the antioxidant response. Next to $\mathrm{NAD}(\mathrm{P}) \mathrm{H}$ dehydrogenase [quinone] 1 (gene: nqo1; protein: Nqo1) [26], heme oxygenase 1 (gene: hmox1; protein: HO1) is among the $n r f 2$ target genes. It catalyzes heme degradation with biliverdin, iron ions, and carbon monoxide (CO) as by-product, and HO-1 has been associated with ROS/RNS-driven oxidative stress responses [27]. A large number of $n r f 2$-independent and dependent proteins are enrolled in the redox signaling pathways, such as peroxiredoxins, glutaredoxins, and thioredoxin [28-30].

Given the importance of ROS/RNS in cancer biology and the prominent role of redox proteins and their subsequent signaling functions, we investigated the responses of eight human cancer lines to plasma-derived ROS/RNS. Specifically, the cellular activity, growth, cytokine/chemokine profile, quantitative expression of immune-relevant cell surface markers, and transcriptional levels of 22 redox-related proteins was investigated. While plasma-derived ROS/RNS were of modest toxicity, hmox 1 was identified as a common responder to that treatment in all eight human cancer cell lines.

\section{Materials and Methods}

\subsection{Cell Culture}

Eight human and referenced (reference number in parentheses) cell lines were used in this work, including SK-Mel 28 (SKM, human malignant melanoma, HTB-72), MNT-1 (MNT1, human malignant melanoma, CVCL_5624), Capan-1 (Capan1, human pancreatic adenocarcinoma, HTB-79), Panc-01 (Panc01, human pancreatic adenocarcinoma, CRL-1469), HT-29 (HT29, human colorectal adenocarcinoma, HTB-38), SW-480 (SW480, human colorectal adenocarcinoma, CCL-228), MCF-7 (MCF7, human mammary adenocarcinoma, HTB-22), and MDA-MB-231 (MDA, human mammary adenocarcinoma, HTB-26). Cells were cultured in Roswell Park Memorial medium (RPMI1640) or Dulbecco's Modified Eagle Medium (DMEM), each supplemented with 10\% fetal bovine serum, 2\% penicillin/streptomycin, and 1\% L-glutamine (all Sigma, Taufkirchen, Germany). For seeding cells in $60 \mathrm{~mm}$ dishes (Sarstedt, Nuembrecht, Germany) at $1 \times 10^{6}$ per dish for transcription experiments or 96-well plates (Eppendorf, Hamburg, Germany) at $1 \times 10^{4}$ per well for all other experiments, accurate viable cell counts were retrieved using flow cytometry (attune; Applied Biosystems; Foster City, CA, USA) and 4',6-Diamidin-2-phenylindol (DAPI; Sigma, Taufkirchen, Germany) to exclude dead cells. After seeding, cells were allowed to attach overnight prior to experimentation. The 96-well plates were equipped with a rim that was filled with phosphate-buffered saline (PBS; Pan Biotech, Aidenbach, Germany) to avoid evaporation in the outer wells. All the cultivations were done at $37^{\circ} \mathrm{C}$, $95 \%$ humidity, and $5 \% \mathrm{CO}_{2}$ in a cell culture incubator (Binder, Tuttlingen, Germany).

\subsection{Plasma-Treated Medium (PTM)}

Plasma-treated medium (PTM) was prepared by exposing $50 \mathrm{~mL}$ of medium in a $250 \mathrm{~mL}$ glass beaker to the plasma of an atmospheric pressure argon plasma jet (kINPen; neoplas, Greifswald, Germany) for $60 \mathrm{~min}$. Control medium was prepared for exposing $50 \mathrm{~mL}$ to argon gas only for 
$60 \mathrm{~min}$. The plasma jet was operated with five standard liters per minute of argon (Air Liquide, Berlin, Germany), at a frequency of $1 \mathrm{Mhz}$, and a total power of less than $3.5 \mathrm{~W}$ in the handheld device. After plasma or argon gas treatment of the liquids, a pre-determined amount of double-distilled water was added to the liquids to compensate for evaporation. Media were then stored at $-20{ }^{\circ} \mathrm{C}$ in aliquots prior to use within seven days. The feasibility of this approach has been documented previously [31-33]. For treatment of cells in $60 \mathrm{~mm}$ dishes, overnight culture medium was removed, cells were washed with PBS, and $5 \mathrm{~mL}$ of PTM or argon gas-treated medium were added to dishes before returning them to the incubator for another $4 \mathrm{~h}$. For the treatment of cells in 96-well plates, overnight culture medium was removed, cells were washed with PBS, and $50 \mu \mathrm{L}$ of PTM or argon-gas treated medium were added to each well (in quadruplicate per condition).

\subsection{Live Cell Imaging}

For live cell imaging, the 96-well plate was placed in a high content imaging device (Operetta CLS, PerkinElmer, Hamburg, Germany) equipped with a temperature module $\left(37^{\circ} \mathrm{C}\right.$ and $\left.5 \% \mathrm{CO}_{2}\right)$. The outer rim of the Eppendorf 96-well plate protected the outer wells from excessive evaporation during the $4 \mathrm{~h}$ of time lapse imaging. Images were acquired with laser-based autofocus every $15 \mathrm{~min}$ with a $20 \times$ air objective (numerical aperture 0.4; Zeiss, Oberkochen, Germany) and a 4.7 megapixels scientific complementary metal-oxide-semiconductor camera (sCMOS). Image mode was digital phase contrast (DPC), a label-free visualization method of the cytosolic area of cells. A standardized de-focusing procedure and software algorithm generates contrast-rich cell areas. More than 20,000 images were acquired across all experiments. After flat-field correction, quantification of these images was carried out with Harmony 4.8 analysis software (PerkinElmer, Hamburg, Germany).

\subsection{Multiplex Chemokine/Cytokine Analysis}

Thirteen different immune-relevant targets were investigated using LegendPlex (BioLegend, London, UK) multi-analyte assay, a bead-based sandwich immuno assay. These beads differ in size and fluorescence intensity and thereby allow for the separate quantification of 13 targets in parallel by flow cytometry. The specific chemokines and cytokines quantified were arginase, CC-chemokine ligand (CLL) 17, C-X-C motif chemokine ligand (CXCL) 1, CXCL10, interferon (IFN) $\gamma$, interleukin (IL)1 $\beta$, IL6, IL8, IL10, IL12, tumor growth factor (TGF) $\beta$, tumor necrosis factor (TNF) $\alpha$, and vascular endothelial growth factor (VEGF). The supernatants were taken before harvesting tumor cells for quantitative polymerase chain reaction (qPCR) experiments, allowing for conclusions from one dataset to the other. The experimental procedure was performed in accordance to the supplier's instructions and the data from flow cytometry (using CytoFLEX S, Beckman-Coulter, Brea, CA, USA) were analyzed using LegendPlex 8.0 analysis software (VigeneTech, Carlisle, MA, USA). Absolute concentrations (in $\mathrm{pg} / \mathrm{mL}$ ) were calculated from an asymmetric sigmoidal model from each target's standard curve.

\subsection{Cell Surface Marker Analysis}

To determine the expression of immunologically relevant surface molecules (Table 1), tumor cells were detached $4 \mathrm{~h}$ after initial exposure to untreated control medium or PTM with accutase (BioLegend, London, UK). After washing with PBS, cells were incubated with DAPI as well as fluorescently-labeled antibodies targeted against cluster of differentiation (CD) 47 PerCP-Cy5.5 (BioLegend, London, UK), calreticulin (CRT) Alexa Fluor (AF) 647 (Novus Biologicals, city, Germany), human leukocyte antigen (HLA)-ABC phycoerythrin (PE)-Cy7 (Becton-Dickinson, Heidelberg, Germany), heat-shock protein (HSP) 70 AF488 (Abcam, Cambridge, UK), and HSP90 AF700 (Novus Biologicals, Cambridge, MA, USA). After incubation for $15 \mathrm{~min}$ in the dark, cells were washed, resuspended, and acquired with a CytoFLEX S flow cytometer (Beckman-Coulter, Brea, CA, USA). Quantification of the mean fluorescent intensities (MFI) was carried out using Kaluza 2.1 analysis software (Beckman-Coulter, Brea, CA, USA). Fluorescence spillover was compensated while using single- and un-stained cells. 
Table 1. Immunogenic cancer cell death (ICD)-related surface molecules investigated in this study.

\begin{tabular}{|c|c|c|}
\hline Abbreviation & Full Name & Physiological Relevance \\
\hline CD47 & $\begin{array}{c}\text { Cluster of } \\
\text { differentiation } 47\end{array}$ & $\begin{array}{l}\text { Serves as "don't eat" me signal by binding CD172a on myeloid cells } \\
\text { to prevent phagocytosis of malignant and non-malignant cells [34] }\end{array}$ \\
\hline CRT & Calreticulin & $\begin{array}{l}\text { ICD marker and serves as "eat-me" signal on non-malignant and } \\
\text { malignant cells to promote phagocytosis by myeloid cells [35] }\end{array}$ \\
\hline HLA-ABC & $\begin{array}{l}\text { Human leukocyte } \\
\text { antigen A, B, and C }\end{array}$ & $\begin{array}{l}\text { Major histocompatibility complex I (MHC class I), serves to present } \\
\text { peptides of endogenous protein to patrolling CD }{ }^{+} \text {T-cells; } \\
\text { important for antitumor immune responses [36] }\end{array}$ \\
\hline HSP70 & Heat-shock protein 70 & $\begin{array}{l}\text { ICD marker, chaperone, and damage-associated molecular pattern } \\
\text { (DAMP) [37] }\end{array}$ \\
\hline HSP90 & Heat-shock protein 90 & $\begin{array}{l}\text { ICD marker, chaperone, and damage-associated molecular pattern } \\
\text { (DAMP) [38] }\end{array}$ \\
\hline
\end{tabular}

\subsection{Quantitative Polymerase Chain Reaction ( $q P C R$ )}

After $4 \mathrm{~h}$ of incubation with control or PTM, the cells were scratched off the dishes and transferred into $1.5 \mathrm{~mL}$ tubes (Eppendorf, Hamburg, Germany). After pelleting and suspending in lysis buffer, RNA isolation was performed according to the protocol of RNA isolation kit (RNA Mini Kit; Bio\&SELL, Feucht, Germany). The RNA concentration of each sample was measured by using the NanoDrop 2000C (Thermo, Waltham, MA, USA) device was aliquoted into micro-tubes for further experiments. For quantitative polymerase chain reaction (qPCR), $1 \mu \mathrm{g}$ of RNA was synthesized into cDNA, according to the manufacturer's instructions (ThermoFisher, Waltham, MA, USA) using a thermocycler (Biometra, Goettingen, Germany). qPCR was performed in white 96-well V-bottom plates with Sybr Green (BioRad, Munich, Germany) labeled targets over 50-cycles using a Light Cycler 480 machine (Roche, Mannheim, Germany). Fold changes in expression was calculated using the $2^{-\Delta \Delta C t}$ method, and normalized against glyceraldehyde 3-phosphate dehydrogenase (gapdh).

\subsection{Statistical Analysis}

Data are from 3-8 independent experiments performed with four technical replicates each. For normalization and calculation with raw data, Excel 2016 (Microsoft, Redmond, WA, USA) was utilized. Statistical analysis was performed with prism 7.05 (GraphPad software, San Diego, CA, USA). Bars show mean and standard error. Statistical comparison was performed either using paired $t$-test, or one-way or two-way analysis of variances (anova) to compare multiple groups. Levels of significance were indicated, as follows: $\alpha=0.05\left(^{*}\right), \alpha=0.001\left(^{* *}\right), \alpha=0.001\left(^{* * *}\right)$.

\section{Results}

\subsection{Plasma-Treated Medium Reduces the Metabolic Activity and Induces Swelling in Tumor Cells}

The kINPen plasma jet (Figure 1a) was used to deposit reactive oxygen and nitrogen species (ROS/RNS) into cell culture medium (plasma-treated medium, PTM). Control or PTM was given to eight different human tumor cells having intrinsic variation in morphology and growth pattern (Figure 1b). After four hours of incubation, the metabolic activity was assessed. A moderate but consistent decreases of metabolic activity was observed among all eight cell lines investigated (Figure 1c). 
a

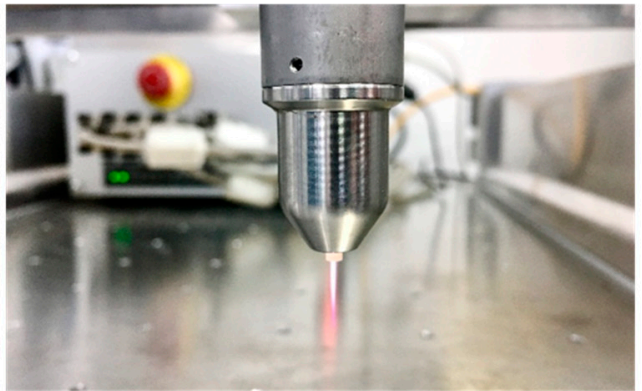

b

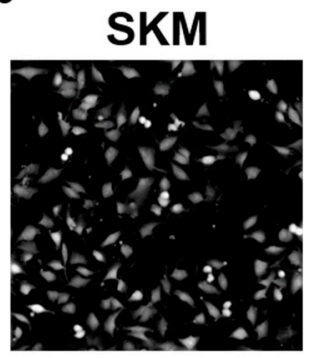

MNT1

Capan1
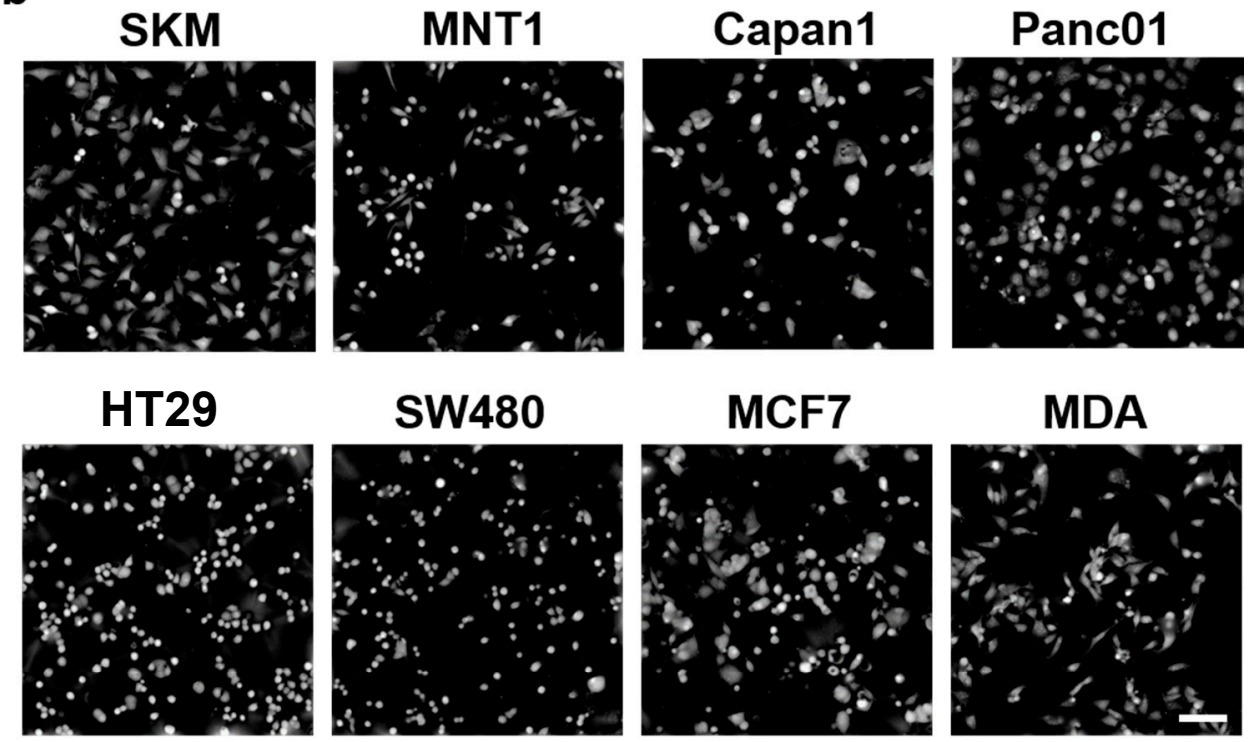

C

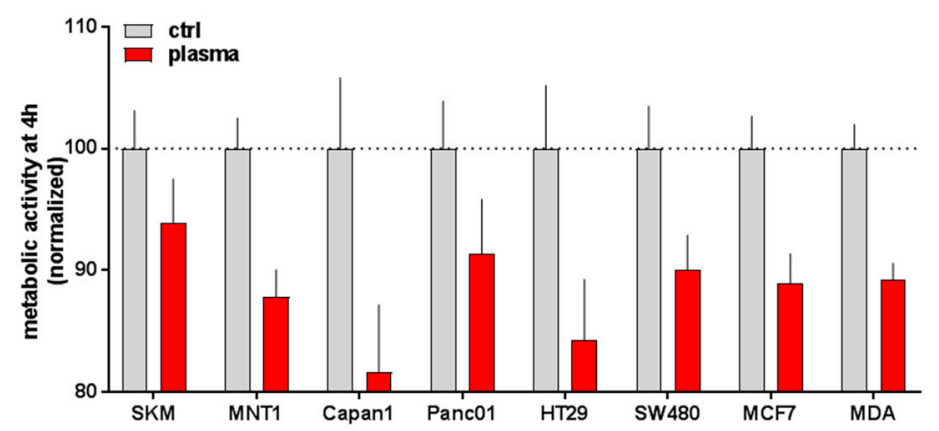

Figure 1. Exposure of initially-seeded $1 \times 10^{4}$ cells of eight human tumor cell lines to plasma-treated medium led to a reduction in metabolic activity. (a) Representative image of the atmospheric pressure argon plasma jet (kINPen) utilized; (b) representative images in digital phase contrast (DPC) mode showing cytosolic fraction of all cell types investigated; (c) metabolic activity (as measured using resazurin) $4 \mathrm{~h}$ following exposure to control or PTM, data are normalized to that of control medium. Data are from 8 independent experiments with four technical replicates each. Scale bar $=100 \mu \mathrm{m}$. Red bars = plasma-treated medium $($ PTM); grey bars = untreated medium (control).

Next, we performed live cell time lapse imaging of all eight cell lines for up to $4 \mathrm{~h}$ following incubation either with control or PTM. For each well, the total cellular cytosolic area (as measure of accumulated cellular spread of all cells identified per field of view) was quantified to normalize to $t=0$ for each sample to monitor changes of time. Except melanoma cells (Figure 2a,b), all cell types showed a significant increase in total cytosolic area (Figure 2c-h). As some these changes were sudden within the first hour after treatment, we attribute this behavior to cellular swelling that is often associated with cellular repair and cycle arrest, which may be linked to the findings of reduced metabolic activity 
(Figure 1c). This effect was particular pronounced in HT29, SW480, and MCF7, and rather moderate in pancreatic tumor cell lines Capan1 and Panc01. Changes in the osmolality of PTM can be excluded as not all cell types exposed to PTM changed (e.g., SKM and MNT1) and some cell types increased their sum cytosolic area also in control medium (e.g., Capan1 and MDA).
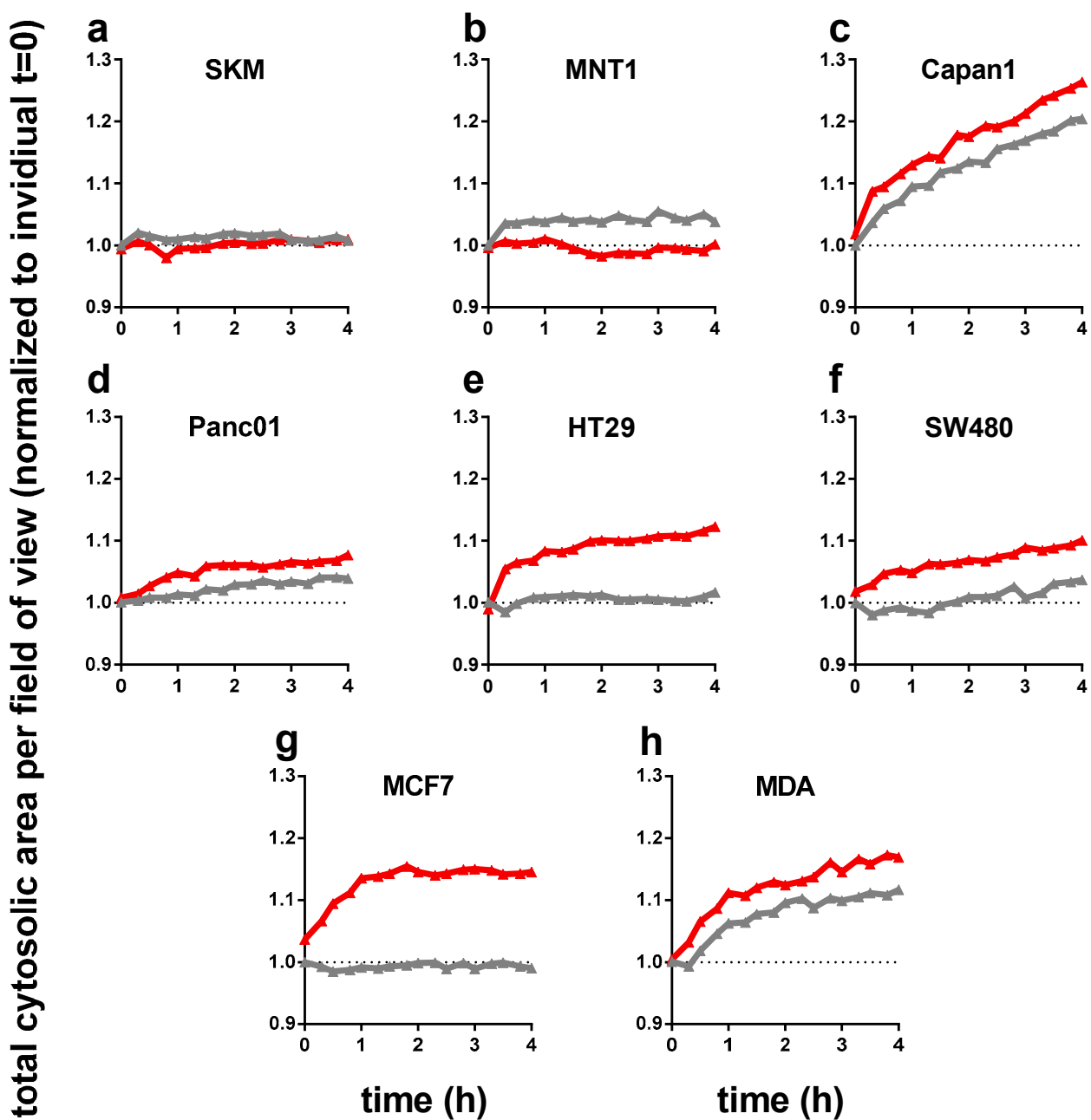

Figure 2. The total cytosolic cell growth area significantly increased with PTM (red) in six out of eight tumor cell lines (in 96-well plates with $1 \times 10^{4}$ cells initially seeded). Time-dynamic data are from high-content microscopy in digital phase contrast mode (indicating cytosolic area, see materials and methods Section 2.3) and summarize data from over 20,000 single images. (a) SK-Mel 28, (b) MNT-1, (c) Capan 1, (d) Panc 01, (e) HT 29, (f) SW 480, (g) MCF7, and (h) MDA-MB-231; untreated medium control and PTM were normalized to each $t=0$. Data are from three independent experiments with four technical replicates each. PTM = plasma-treated medium (red lines); control = untreated medium (grey lines).

3.2. Baseline and Regulated Transcriptional Level 22 Redox-Related Genes in Eight Human Cancer Cell Lines Following Exposure to Physical Plasma-Derived Oxidants

In further experiments, we sought to profile in all eight cancer cell lines the transcriptional level of 22 redox-related genes that may be associated with the perception of ROS/RNS released by physical plasma into cell culture medium. To gain a better understanding of the differences among all cell lines, a mini redox-map was generated to assess the baseline expression levels of all targets investigated via qPCR (Figure 3a). Using gapdh levels as cell-specific normalization control, endoplasmic Reticulum protein $27.7 \mathrm{kDa}$ (erp27), erp4, nqo1, protein disulfide-isomerase/beta-subunit of prolyl 4-hydroxylase $(p 4 h b)$, protein disulfide isomerase family A member 3 (pdia3), peroxiredoxin 5 (prdx5), and prdx6, as well 
as thioredoxin related transmembrane protein $1(t m x 1)$ and $t m x 3$ showed a medium to high expression in cells cultured in control medium. Transcripts of $g \operatorname{lr} x 1, n x n$, and $p r d x 4$ were not detected in any cell line. Moreover, the expression of $n r f 2, n q o 1$, and hmox1 is shown in comparison to gapdh at higher resolution as these targets are known to be modulated upon oxidative stress (Figure $3 b$ ). A relatively low expression of $n r f 2$ in all eight cell lines is observed, whereas nqo1 is mostly highly expressed. The biggest differences of expression between all cell lines investigated can be seen for hmox1.

a

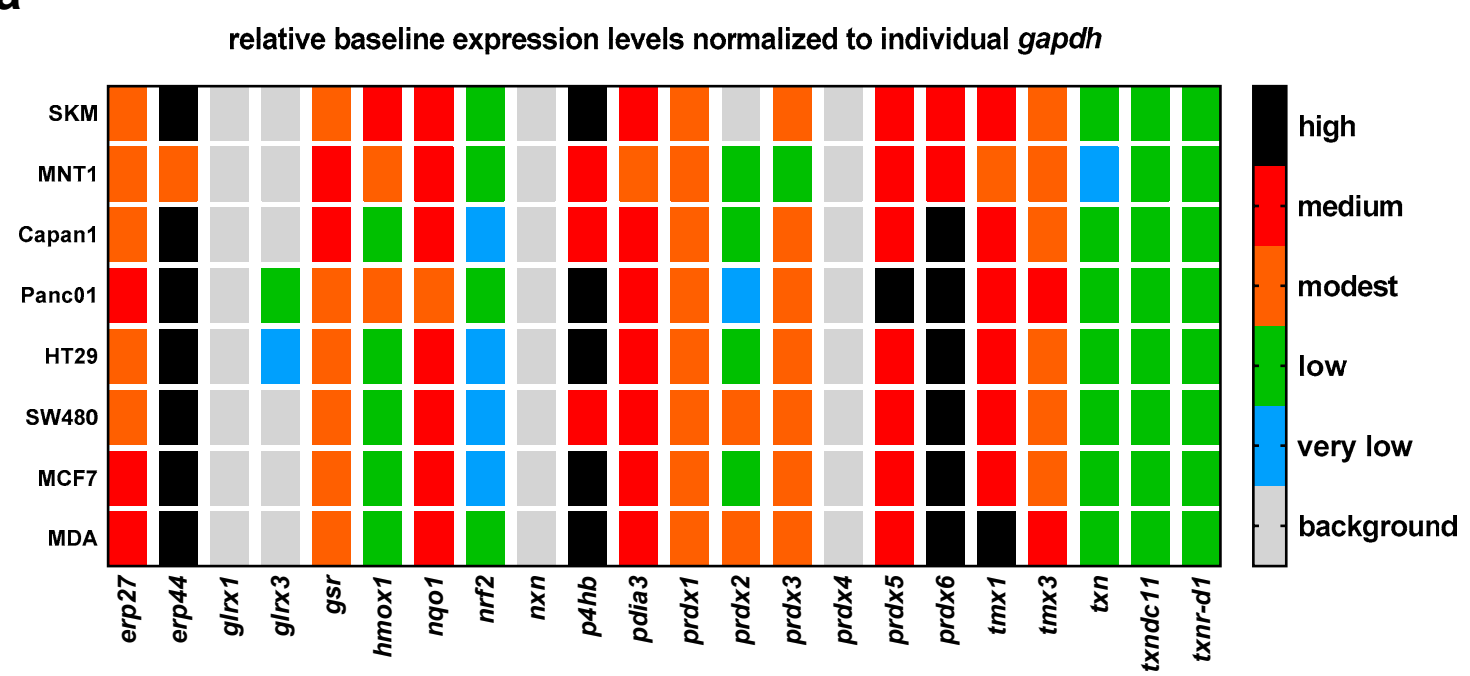

b

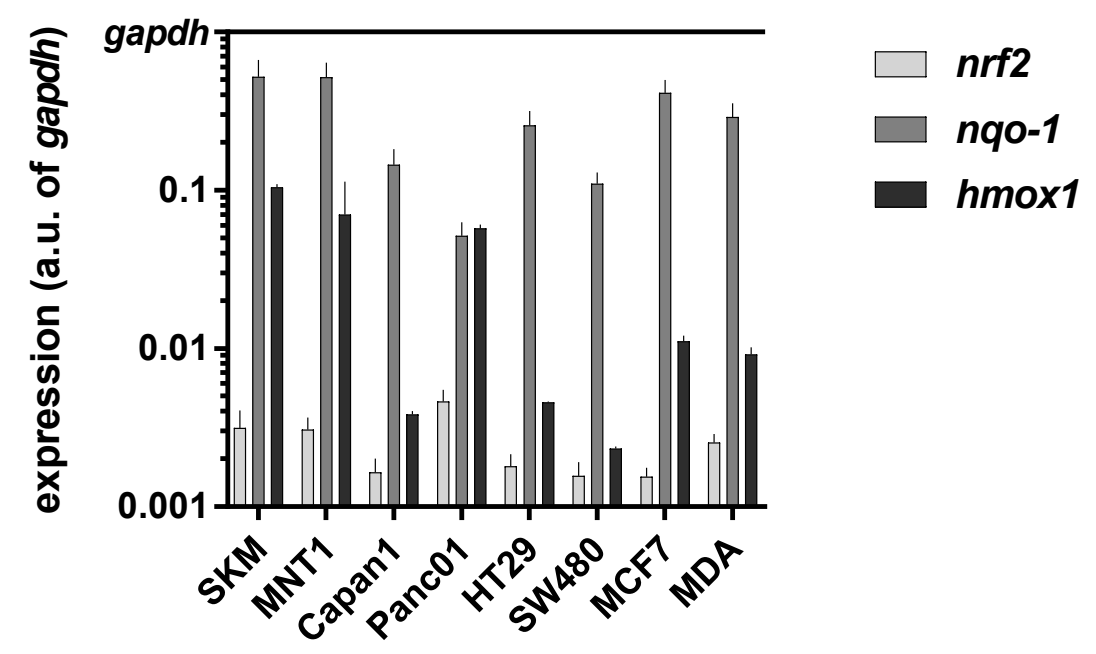

Figure 3. Heat map of transcriptional levels of 22 redox-related proteins in relation to cell line-specific levels of the house keeping gene gapdh as assessed via qPCR. (a) relative baseline values for all transcripts investigated in eight different human cell lines; (b) data from heat map represented for three targets known to respond to oxidative stress (nrf2, nqo1, and hmox1) for better individual comparison. Data are from three to four independent experiments.

Having investigated the baseline transcriptional expression levels of 22 redox-related proteins in eight human cancer cell lines, we investigated their up or downregulation following exposure to PTM at $4 \mathrm{~h}$. We did not identify a consistent change with all except one target (hmox1) quantified across all cell lines used in this study (Figure 4a). A mixed response was observed for $g l r x 1, \operatorname{prd} x 1$, and $\operatorname{prd} x 5$. A more detailed analysis display of $h \operatorname{mox} 1$ data revealed a pronounced upregulation, particularly with HT29, SW480, and MCF7 cells (Figure 4b). As hmox1 is known to be a target of $n r f 2$, correlation analysis was performed between baseline $n f r 2$ expression levels and hmox 1 expression levels induced with 
PTM. A significant inverse correlation was observed between both factors (Figure 4c). Especially for the three cell lines with high upregulation of hmox 1 following PTM exposure, a rather low nrf2 baseline expression was observed. Interestingly, through quantification of the DPC signal after challenging the cells with ROS/RNS, we found a correlation between the expression of hmox1 and the change in cytosolic area (Figure 4d). Hence, a high hmoxl expression is characteristic, together with an increased cell area after PTM treatment.

a

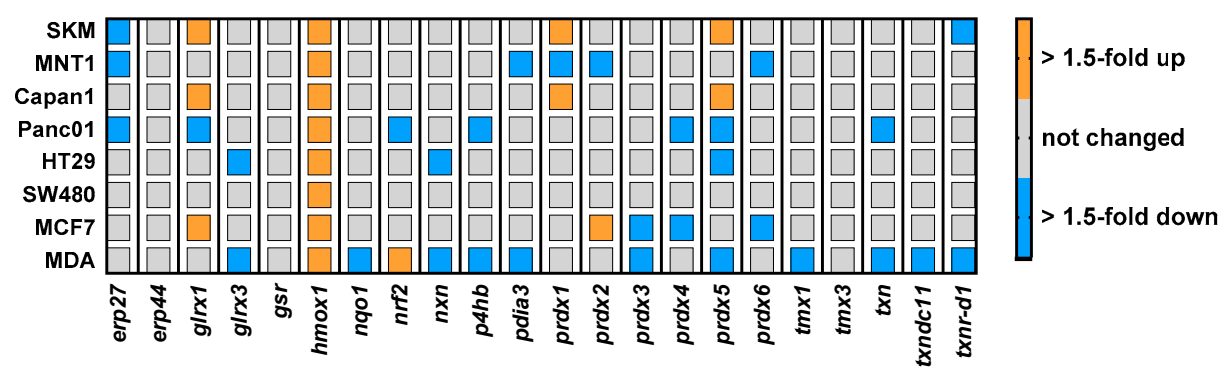

b

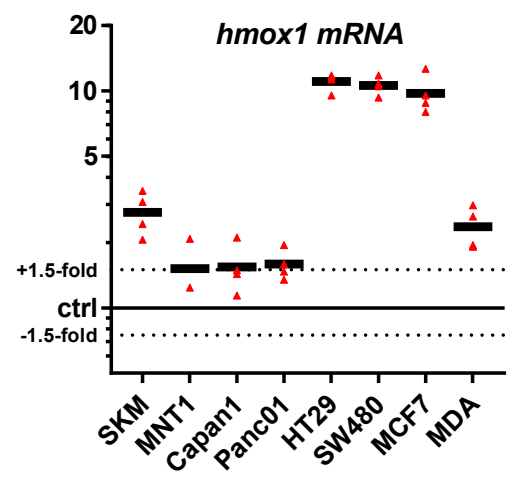

C

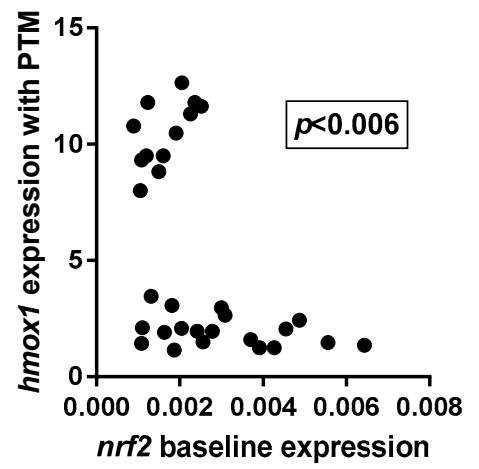

d

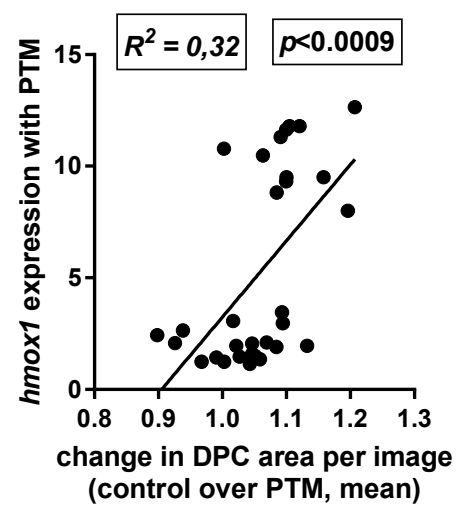

Figure 4. Exposure to PMT modulated transcriptional levels of several redox-related proteins with a consistent increase in hmox 1 transcripts across all eight human cancer cell lines investigated. Gene expression of redox-related enzymes, with upregulation of $g l r x 1$ and $h m o x 1$, and a mixed response for peroxiredoxin genes, especially prx 1 and prx5. (a) qPCR of all target transcripts as fold change of PTM-treatment over medium control; (b) detailed expression levels of $h$ mox 1 in all cell lines investigated; (c) relation between hmox1 upregulation with PTM treatment and $n r f 2$ expression of cells incubated with control medium; (d) correlation of total cytosolic area determined as DPC area in high-content imaging experiments $4 \mathrm{~h}$ post plasma-treatment and expression of hmox1. Data are from three to four independent experiments. (b) each triangle and $(\mathbf{c}, \mathbf{d})$ each dot represents one biological replicate of one cell lines for the indicated markers. 


\subsection{Modest Changes in the Immunomodulatory Profile in Response to PTM in Eight Human Cancer Cell Lines}

Having analyzed the tumor-static effects of PTM with subsequent changes in the transcriptional profile of 22 redox-related proteins, we sought to investigate immunomodulatory effects of PTM treatment. An expression of hmox1 is known to be tightly associated with inflammation [39]. Essential for such immune reaction is the secretion of inflammatory mediators. Therefore, we determined such soluble mediators in the cells supernatant and found that PTM induced a complex secretion profile of chemokines and cytokines in the different cell lines (Figure 5a-m). A significantly higher secretion of the pro-inflammatory mediators CXCL10 (in Capan1), arginase (in MDA), and TNF $\alpha$ (in HT29) was found, as well as a higher secretion of the anti-inflammatory interleukin 10 (in HT29) and the depletion of IL8 (in SKM) and arginase (in SKM, Panc01, HT29, and MDA). However, to evaluate the immunogenic effect of the secretion of different factors a more complex model, including different cell types is needed and our observations suggest a mixed response.

a

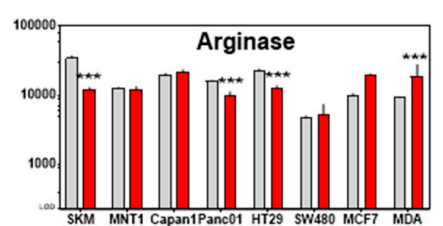

름

d

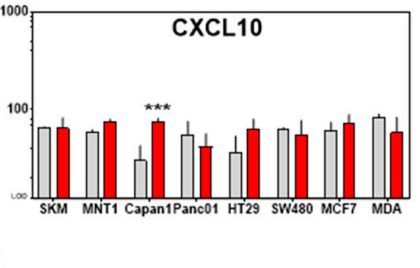

g

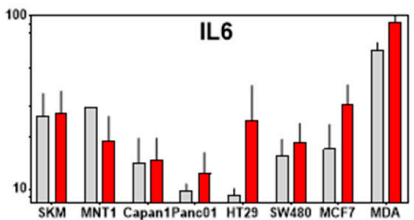

j

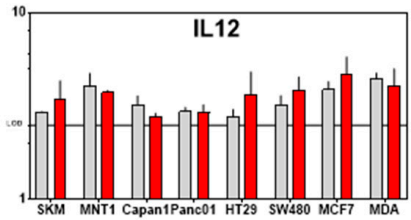

b

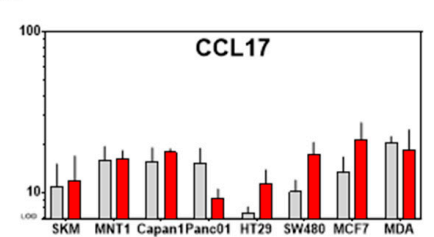

e

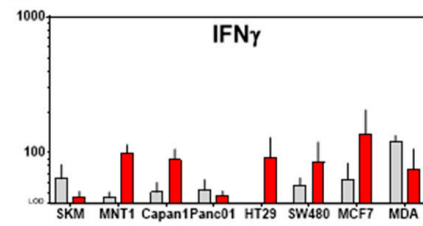

h

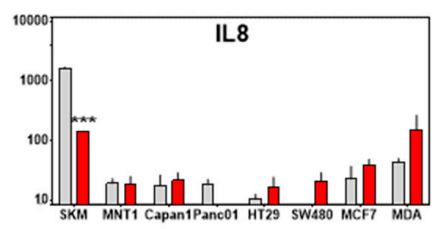

k

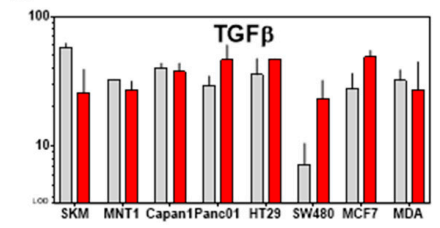

m

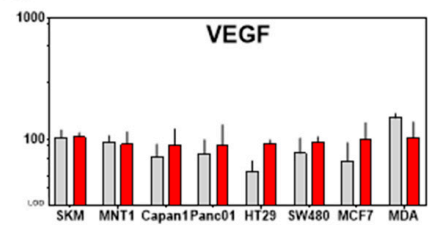

C

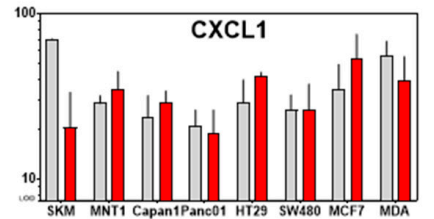

f

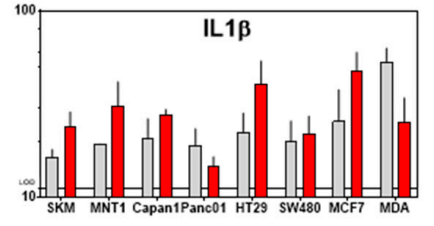

i

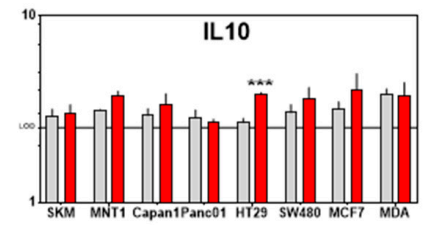

I

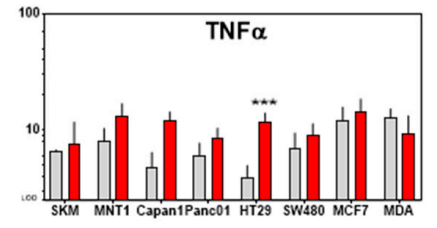

Figure 5. Exposure to PTM alters the chemokine/cytokine profile in supernatants of eight human cancer cell lines. Quantification of (a) arginase, (b) CCL17, (c) CXCL1, (d) CXCL10, (e) IFN $\gamma$, (f) IL1 $\beta$, (g) IL6, (h) IL8, (i) IL10, (j) IL12, (k) TGF $\beta$, (1) TNF $\alpha$, and (m) VEGF; all concentrations are $\mathrm{pg} / \mathrm{mL}$; lines indicate the target-specific limit of detection (LOD). Data are pooled from eight independent experiments. Red bars = plasma-treated medium (PTM); grey bars = untreated medium (control). 
Moreover, previous studies indicated that tumor-toxic concentrations of plasma-derived ROS/RNS are capable of inducing the immunogenic cancer cell death (ICD) [40]. This type of cell death promotes antitumor immune responses, and is characterized by release upregulation of a number of molecules on the cell membrane, such as calreticulin (CRT), major histocompatibility complex I (MHC class I; HLA-ABC), and heat-shock proteins (HSP) 70 and 90 [41]. This may be accompanied by a downregulation of CD47, which promotes the phagocytosis of tumor cells [34]. However, only SK-Mel 28 (SKM) cells showed a considerable increase of HSP90 on the membrane of living cells (Figure 6a). For all other surface molecules and cell lines, there were only minor changes that were observed in response to PTM at $4 \mathrm{~h}$ when normalized each respective control (Figure $6 \mathrm{~b}$ ). This may be due to the overall mild effect (short plasma treatment time) of the PTM.

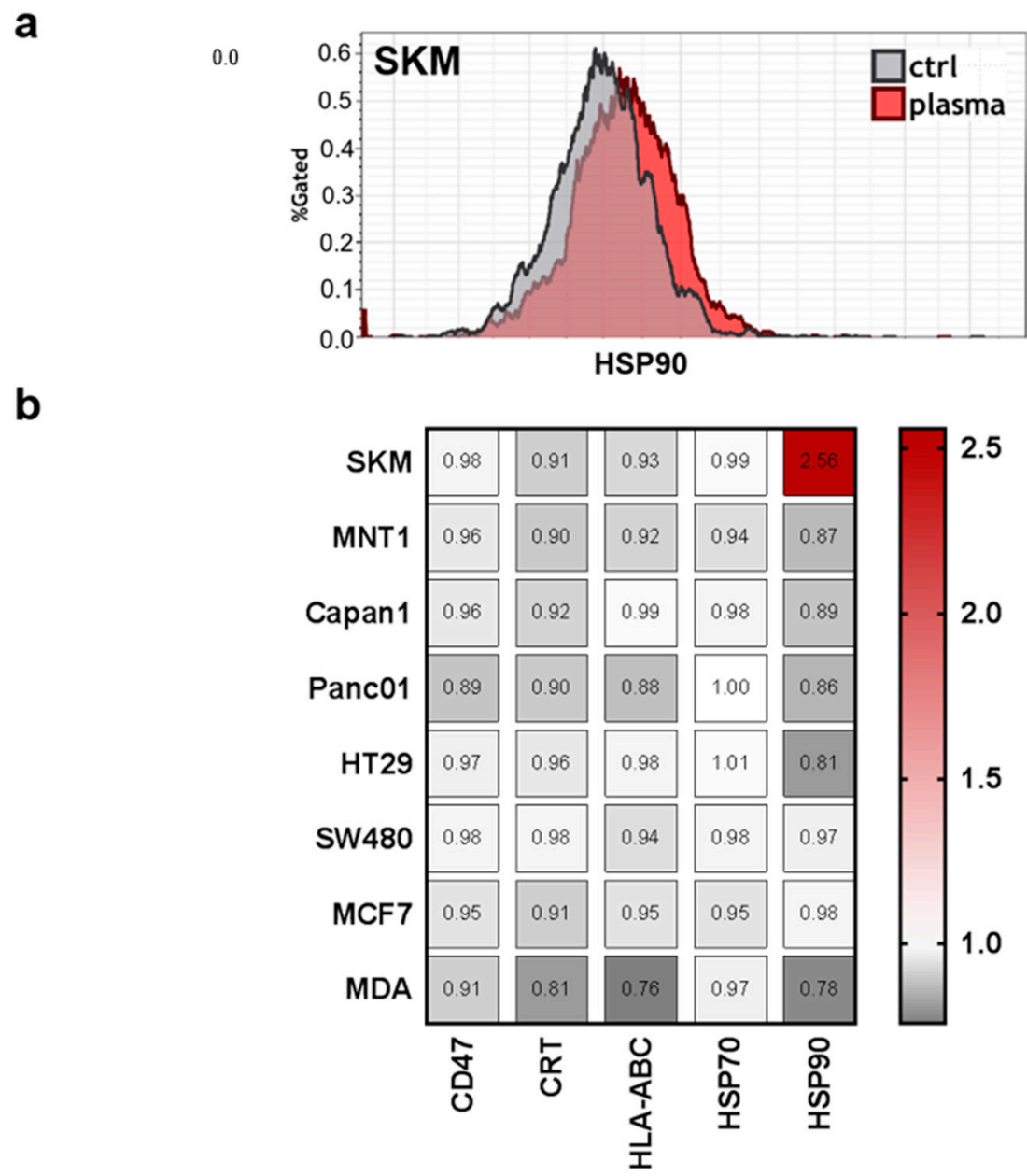

Figure 6. Expression of immune-response relevant surface markers remains predominantly unchanged after plasma treatment. Cells were harvested, stained with anti-cluster of differentiation 47 (CD47, PerCP-Cy5.5), anti-calreticulin (CRT, AF647), anti-human leucocyte antigen ABC (HLA-ABC, PE-Cy), anti-heat-shock protein 70 (HSP70, AF488), and anti-heat-shock protein 90 (HSP90, AF700) and were measured by flow-cytometry. (a) Representative overlay of expression of HSP90 in SKM28 cells; (b) quantification of mean fluorescence intensities (MFIs) on viable cells normalized on each's cell lines untreated medium control.

\section{Discussion}

In need of a common marker delineating the response of cancer cells to plasma-treated medium (PTM), we studied of growth behavior, immunogenic features, and the expression of 22 redox-related transcripts in eight human cancer cell lines. Besides presenting a small redox map in all cell types with 
regard to baseline redox-protein transcript expression and chemokine/cytokine profile, hmox1 was identified as key response element in all cancer cell lines following exposure to PTM.

Angiogenesis is a key hallmark of cancer [42]. New blood vessel help support tumor growth by removing metabolic waste and carbon dioxide, and increasing nutrient supply. Induced by VEGF and $n r f 2$ as well as others, heme oxygenase 1 (HO1, hmox1) derived carbon monoxide (CO) possess not only proangiogenic effects, but also anti-inflammatory, antioxidant, and anti-apoptotic properties [43]. HO1 moreover detoxifies heme into ferrous iron, as the former would otherwise contribute to the cytotoxic fenton reaction generating hydroxyl radicals [44]. HO1 has therefore implicated as major target in cancer therapy although its expression is linked to both tumor progression and regress [45]. Oxidative stress is a known inducer of HO1 in human cells [46,47], underlining reactive oxygen and nitrogen species being a major bio-active component in physical plasma-treated liquids. Indeed, both human keratinocytes [48] and the human cell line THP-1 monocytes [49] upregulate hmox1 in response to plasma-derived ROS/RNS.

While the identification of a common hmox1 signature in response to PTM may be useful for further research, the consequences on tumor metastasis in vivo are controversial. In breast cancer cells, we found a strong increase in hmox1 levels after PTM exposure, and such an upregulation was shown to be associated with a significant reduction of invasive properties in MCF7 and MDA-MB-231 cells [50]. Similar observations were made with colon cancer cells [51,52]. As a mechanism, the inhibition of matrix-metalloproteinase (MMPs) through HO1-derived CO was proposed, as MMPs facilitate the degradation of extracellular matrix needed for metastatic spread. However, several reports argue for a role of HO1 in promoting metastatic spread in cancer [53-55]. This is linked especially to its constitutive upregulation in many types of tumors as well as studies showing that hmox1 downregulation is associated with better outcome. Specifically, among non-responders to chemotherapy in a cohort of head and neck cancer patients, hmox 1 was the most upregulated gene that is identified in a transcriptomic microarray study as compared to complete responders [56].

Hmox 1 expression is tightly linked to regulation of immunity and inflammation [39]. Investigating a panel of well-recognized markers for immunogenic cell death (ICD) that are involved in immunological recognition and removal of tumor cells $[41,57,58]$, we identified only heat-shock protein 90 (HSP90) to be upregulated in SK-Mel 28 cells. However, the profound upregulation of HSP90 on SK-Mel 28 cell membrane in response to low-dose oxidative stress may be a valuable research target for tumor immunology. HSP90 is a damage-associated molecular pattern (DAMP) that can facilitate the uptake of tumor cells by dendritic cells to induce antitumor immune responses [59]. Release of DAMPs and enhanced expression of ICD-relevant markers has been shown for plasma-derived ROS/RNS in various type of tumor cells [60-62]. Yet, our PTM was rather tumor-static than tumor-toxic, possibly contributing to the lack modulation with all except one marker in almost all cell lines. With respect to the three cell lines (HT29, SW480, MCF7) with the strongest increase in hmox1 levels, a number of chemokines/cytokines/growth factors were all increased in tendency in response to PTM, namely CCL17, IFN $\gamma$, IL1 $\beta$, IL6, IL8, IL10, IL12, TGF $\beta$, TNF $\alpha$, and VEGF. A correlation between increase of hmox 1 and IL8 as well as VEGF was reported before being major angiogenic drivers in tissues [63]. In a murine carcinogenesis model, IL1 $\beta$ models for only non-significantly increased with a significant increase in hmox1 [64], corroborating our findings. HO1 is also described to increase IL10 production [65], as seen in our subset of cell with high hmox1 expression. In general, this subsets had a consistent increase in both pro-inflammatory (CCL17, CCL17, IFN $\gamma$, IL1 $\beta$, IL6, IL12, and TNF $\alpha$ ) and anti-inflammatory (IL8, IL10, TGF $\beta$, and VEGF) cytokines, underlining the complex effects that HO1 has on inflammation.

The effect-inducing agent in our study was cell culture medium exposed to cold physical plasma, a partially ionized gas operated at room temperature. A number of reactive oxygen and nitrogen species were so far identified in plasma-treated liquids [66], among them e.g., superoxide anion, singlet oxygen, nitrite, nitrate, peroxynitrite, hydrogen peroxide, hydroxyl radical, nitric oxide, ozone, and atomic oxygen [67-71]. However, most of these species quickly deteriorate to some major long-lived 
oxidants, which are likely to mediate the main effect that was observed with PTM. Only recently, reports dealt with post-translational modifications on biomolecules and proteins that are present in liquid media [72], which may be recognized by cells and their oxidation-sensitive receptor repertoire. Oxidative stress is sensed through the $n r f 2 /$ Keap1 pathway [73], which leads to the activation of antioxidative responses elements (ARE), including transcriptional targets, such as vegf, hmox1, bach1, fos, junb/d, maf, and others [74]. While we here identified a consistent upregulation of $h m o x 1$ in eight tumor cell types following exposure to PTM, no changes in $n r f 2$ levels were observed. This is consistent with a previous report in human keratinocytes were $n r f 2 \mathrm{mRNA}$ levels peaked at $20 \mathrm{~min}$ following exposure to PTM, whereas that of hmox1 peaked at $3 \mathrm{~h}$ [75].

\section{Conclusions}

The main aim of this study was to identify a common redox-related transcriptional signature in eight human cancer lines following exposure to physical plasma-treated medium (PTM). We not only identified transcriptional levels of $h$ mox 1 as mutual response element but also provided useful tools, such as a 22 target transcriptional map and cytokine/chemokine patterns in all cell lines to further study the role of other redox proteins that signal with plasma-derived ROS/RNS.

Author Contributions: Conceptualization, S.B. and A.S.; methodology, S.B and A.S.; formal analysis, S.B. and E.F.; investigation, E.F. and K.K.C.; resources, S.B. and K.W.; writing-original draft preparation, S.B., E.F., and K.W.; writing-review and editing, all authors; visualization, S.B.; supervision, S.B.; project administration, S.B., R.G., and A.S.; funding acquisition, S.B. and K.W.

Funding: This research was funded by the German Federal Ministry of Education and Research (BMBF), grant numbers 03Z22DN11 and 03Z22DN12.

Acknowledgments: Technical assistance by Kan-Kau Chow and Felix Niessner is greatly acknowledged.

Conflicts of Interest: The authors declare no conflict of interest. The funders had no role in the design of the study; in the collection, analyses, or interpretation of data; in the writing of the manuscript, or in the decision to publish the results.

\section{References}

1. Nagai, H.; Kim, Y.H. Cancer prevention from the perspective of global cancer burden patterns. J. Thorac. Dis. 2017, 9, 448-451. [CrossRef] [PubMed]

2. Brigger, I.; Dubernet, C.; Couvreur, P. Nanoparticles in cancer therapy and diagnosis. Adv. Drug Del. Rev. 2012, 64, 24-36. [CrossRef]

3. Bown, S.; Pereira, S. Pdt for cancer of the pancreas-The story so far. Photodiagn. Photodyn. Ther. 2017, 17, A28. [CrossRef]

4. Moserova, I.; Truxova, I.; Garg, A.D.; Tomala, J.; Agostinis, P.; Cartron, P.F.; Vosahlikova, S.; Kovar, M.; Spisek, R.; Fucikova, J. Caspase-2 and oxidative stress underlie the immunogenic potential of high hydrostatic pressure-induced cancer cell death. Oncoimmunology 2017, 6, e1258505. [CrossRef] [PubMed]

5. Um, W.; Kwon, S.; You, D.G.; Cha, J.M.; Kim, H.R.; Park, J.H. Non-thermal acoustic treatment as a safe alternative to thermosensitive liposome-involved hyperthermia for cancer therapy. RSC Adv. 2017, 7, 29618-29625. [CrossRef]

6. Reuter, U.R.M.; Oettmeier, R.; Hobohm, U. Safety of therapeutic fever induction in cancer patients using approved pamp drugs. Transl. Oncol. 2018, 11, 330-337. [CrossRef] [PubMed]

7. Kwon, H.M.; Kang, E.J.; Kang, K.; Kim, S.D.; Yang, K.; Yi, J.M. Combinatorial effects of an epigenetic inhibitor and ionizing radiation contribute to targeted elimination of pancreatic cancer stem cell. Oncotarget 2017, 8 , 89005-89020. [CrossRef] [PubMed]

8. Yan, D.; Sherman, J.H.; Keidar, M. Cold atmospheric plasma, a novel promising anti-cancer treatment modality. Oncotarget 2017, 8, 15977-15995. [CrossRef] [PubMed]

9. Laroussi, M.; Lu, X.; Keidar, M. Perspective: The physics, diagnostics, and applications of atmospheric pressure low temperature plasma sources used in plasma medicine. J. Appl. Phys. 2017, 122, 020901. [CrossRef] 
10. Ahn, H.J.; Kim, K.I.; Hoan, N.N.; Kim, C.H.; Moon, E.; Choi, K.S.; Yang, S.S.; Lee, J.S. Targeting cancer cells with reactive oxygen and nitrogen species generated by atmospheric-pressure air plasma. PLoS ONE 2014, 9, e86173. [CrossRef] [PubMed]

11. Chen, Z.; Simonyan, H.; Cheng, X.; Gjika, E.; Lin, L.; Canady, J.; Sherman, J.H.; Young, C.; Keidar, M. A novel micro cold atmospheric plasma device for glioblastoma both in vitro and in vivo. Cancers (Basel) 2017, 9, 61. [CrossRef] [PubMed]

12. Weiss, M.; Gumbel, D.; Gelbrich, N.; Brandenburg, L.O.; Mandelkow, R.; Zimmermann, U.; Ziegler, P.; Burchardt, M.; Stope, M.B. Inhibition of cell growth of the prostate cancer cell model lncap by cold atmospheric plasma. In Vivo 2015, 29, 611-616. [PubMed]

13. Gumbel, D.; Suchy, B.; Wien, L.; Gelbrich, N.; Napp, M.; Kramer, A.; Ekkernkamp, A.; Daeschlein, G.; Stope, M.B. Comparison of cold atmospheric plasma devices' efficacy on osteosarcoma and fibroblastic in vitro cell models. Anticancer Res. 2017, 37, 5407-5414. [CrossRef] [PubMed]

14. Kim, S.Y.; Kim, H.J.; Kang, S.U.; Kim, Y.E.; Park, J.K.; Shin, Y.S.; Kim, Y.S.; Lee, K.; Kim, C.H. Non-thermal plasma induces AKT degradation through turn-on the MUL1 E3 ligase in head and neck cancer. Oncotarget 2015, 6, 33382-33396. [CrossRef] [PubMed]

15. Utsumi, F.; Kajiyama, H.; Nakamura, K.; Tanaka, H.; Mizuno, M.; Ishikawa, K.; Kondo, H.; Kano, H.; Hori, M.; Kikkawa, F. Effect of indirect nonequilibrium atmospheric pressure plasma on anti-proliferative activity against chronic chemo-resistant ovarian cancer cells in vitro and in vivo. PLoS ONE 2013, 8, e81576. [CrossRef] [PubMed]

16. Vandamme, M.; Robert, E.; Lerondel, S.; Sarron, V.; Ries, D.; Dozias, S.; Sobilo, J.; Gosset, D.; Kieda, C.; Legrain, B.; et al. Ros implication in a new antitumor strategy based on non-thermal plasma. Int. J. Cancer 2012, 130, 2185-2194. [CrossRef] [PubMed]

17. Bekeschus, S.; Kading, A.; Schroder, T.; Wende, K.; Hackbarth, C.; Liedtke, K.R.; van der Linde, J.; von Woedtke, T.; Heidecke, C.D.; Partecke, L.I. Cold physical plasma treated buffered saline solution as effective agent against pancreatic cancer cells. Anticancer Agents Med. Chem. 2018, 18. [CrossRef] [PubMed]

18. Liedtke, K.R.; Bekeschus, S.; Kaeding, A.; Hackbarth, C.; Kuehn, J.P.; Heidecke, C.D.; von Bernstorff, W.; von Woedtke, T.; Partecke, L.I. Non-thermal plasma-treated solution demonstrates antitumor activity against pancreatic cancer cells in vitro and in vivo. Sci. Rep. 2017, 7, 8319. [CrossRef] [PubMed]

19. Tanaka, H.; Nakamura, K.; Mizuno, M.; Ishikawa, K.; Takeda, K.; Kajiyama, H.; Utsumi, F.; Kikkawa, F.; Hori, M. Non-thermal atmospheric pressure plasma activates lactate in ringer's solution for anti-tumor effects. Sci. Rep. 2016, 6, 36282. [CrossRef] [PubMed]

20. Metelmann, H.R.; Seebauer, C.; Rutkowski, R.; Schuster, M.; Bekeschus, S.; Metelmann, P. Treating cancer with cold physical plasma: On the way to evidence-based medicine. Contrib. Plasma Phys. 2018, 58, 415-419. [CrossRef]

21. Metelmann, H.-R.; Seebauer, C.; Miller, V.; Fridman, A.; Bauer, G.; Graves, D.B.; Pouvesle, J.-M.; Rutkowski, R.; Schuster, M.; Bekeschus, S.; et al. Clinical experience with cold plasma in the treatment of locally advanced head and neck cancer. Clin. Plasma Med. 2018, 9, 6-13. [CrossRef]

22. Rutkowski, R.; Schuster, M.; Unger, J.; Seebauer, C.; Metelmann, H.R.; Woedtke, T.V.; Weltmann, K.D.; Daeschlein, G. Hyperspectral imaging for in vivo monitoring of cold atmospheric plasma effects on microcirculation in treatment of head and neck cancer and wound healing. Clin. Plasma Med. 2017, 7-8, 52-57. [CrossRef]

23. Zeegers, D.; Venkatesan, S.; Koh, S.W.; Low, G.K.; Srivastava, P.; Sundaram, N.; Sethu, S.; Banerjee, B.; Jayapal, M.; Belyakov, O.; et al. Biomarkers of ionizing radiation exposure: A multiparametric approach. Genome Integr. 2017, 8, 6. [CrossRef] [PubMed]

24. De Souza, A.L.R.; LaRochelle, E.; Marra, K.; Gunn, J.; Davis, S.C.; Samkoe, K.S.; Chapman, M.S.; Maytin, E.V.; Hasan, T.; Pogue, B.W. Assessing daylight \& low-dose rate photodynamic therapy efficacy, using biomarkers of photophysical, biochemical and biological damage metrics in situ. Photodiagn. Photodyn. Ther. 2017, 20, 227-233. [CrossRef]

25. O'Connell, M.A.; Hayes, J.D. The Keap1/nrf2 pathway in health and disease: From the bench to the clinic. Biochem. Soc. Trans. 2015, 43, 687-689. [CrossRef] [PubMed]

26. Schmidt, A.; Bekeschus, S. Redox for repair: Cold physical plasmas and $n r f 2$ signaling promoting wound healing. Antioxidants (Basel) 2018, 7, 146. [CrossRef] [PubMed] 
27. Loboda, A.; Damulewicz, M.; Pyza, E.; Jozkowicz, A.; Dulak, J. Role of nrf2/HO-1 system in development, oxidative stress response and diseases: An evolutionarily conserved mechanism. Cell. Mol. Life Sci. 2016, 73, 3221-3247. [CrossRef] [PubMed]

28. Chorley, B.N.; Campbell, M.R.; Wang, X.; Karaca, M.; Sambandan, D.; Bangura, F.; Xue, P.; Pi, J.; Kleeberger, S.R.; Bell, D.A. Identification of novel NRF2-regulated genes by ChIP-Seq: Influence on retinoid X receptor alpha. Nucleic Acids Res. 2012, 40, 7416-7429. [CrossRef] [PubMed]

29. Hanschmann, E.M.; Godoy, J.R.; Berndt, C.; Hudemann, C.; Lillig, C.H. Thioredoxins, glutaredoxins, and peroxiredoxins-Molecular mechanisms and health significance: From cofactors to antioxidants to redox signaling. Antioxid. Redox Signal. 2013, 19, 1539-1605. [CrossRef] [PubMed]

30. Kim, Y.J.; Ahn, J.Y.; Liang, P.; Ip, C.; Zhang, Y.; Park, Y.M. Human prx1 gene is a target of $n r f 2$ and is up-regulated by hypoxia/reoxygenation: Implication to tumor biology. Cancer Res. 2007, 67, 546-554. [CrossRef] [PubMed]

31. Judee, F.; Fongia, C.; Ducommun, B.; Yousfi, M.; Lobjois, V.; Merbahi, N. Short and long time effects of low temperature plasma activated media on 3D multicellular tumor spheroids. Sci. Rep. 2016, 6, 21421. [CrossRef] [PubMed]

32. Adachi, T.; Tanaka, H.; Nonomura, S.; Hara, H.; Kondo, S.; Hori, M. Plasma-activated medium induces A549 cell injury via a spiral apoptotic cascade involving the mitochondrial-nuclear network. Free Radic. Biol. Med. 2015, 79, 28-44. [CrossRef] [PubMed]

33. Hoentsch, M.; Bussiahn, R.; Rebl, H.; Bergemann, C.; Eggert, M.; Frank, M.; von Woedtke, T.; Nebe, B. Persistent effectivity of gas plasma-treated, long time-stored liquid on epithelial cell adhesion capacity and membrane morphology. PLoS ONE 2014, 9, e104559. [CrossRef] [PubMed]

34. Chao, M.P.; Jaiswal, S.; Weissman-Tsukamoto, R.; Alizadeh, A.A.; Gentles, A.J.; Volkmer, J.; Weiskopf, K.; Willingham, S.B.; Raveh, T.; Park, C.Y.; et al. Calreticulin is the dominant pro-phagocytic signal on multiple human cancers and is counterbalanced by CD47. Sci. Transl. Med. 2010, 2, 63ra94. [CrossRef] [PubMed]

35. Obeid, M.; Tesniere, A.; Ghiringhelli, F.; Fimia, G.M.; Apetoh, L.; Perfettini, J.L.; Castedo, M.; Mignot, G.; Panaretakis, T.; Casares, N.; et al. Calreticulin exposure dictates the immunogenicity of cancer cell death. Nat. Med. 2007, 13, 54-61. [CrossRef] [PubMed]

36. Boegel, S.; Lower, M.; Bukur, T.; Sahin, U.; Castle, J.C. A catalog of HLA type, HLA expression, and neo-epitope candidates in human cancer cell lines. Oncoimmunology 2014, 3, e954893. [CrossRef] [PubMed]

37. Fucikova, J.; Moserova, I.; Truxova, I.; Hermanova, I.; Vancurova, I.; Partlova, S.; Fialova, A.; Sojka, L.; Cartron, P.F.; Houska, M.; et al. High hydrostatic pressure induces immunogenic cell death in human tumor cells. Int. J. Cancer 2014, 135, 1165-1177. [CrossRef] [PubMed]

38. Adkins, I.; Sadilkova, L.; Hradilova, N.; Tomala, J.; Kovar, M.; Spisek, R. Severe, but not mild heat-shock treatment induces immunogenic cell death in cancer cells. Oncoimmunology 2017, 6, e1311433. [CrossRef] [PubMed]

39. Ryter, S.W.; Choi, A.M. Targeting heme oxygenase-1 and carbon monoxide for therapeutic modulation of inflammation. Transl. Res. 2016, 167, 7-34. [CrossRef] [PubMed]

40. Galluzzi, L.; Kepp, O.; Kroemer, G. Enlightening the impact of immunogenic cell death in photodynamic cancer therapy. EMBO J. 2012, 31, 1055-1057. [CrossRef] [PubMed]

41. Kroemer, G.; Galluzzi, L.; Kepp, O.; Zitvogel, L. Immunogenic cell death in cancer therapy. Annu. Rev. Immunol. 2013, 31, 51-72. [CrossRef] [PubMed]

42. Abdollahi, A.; Folkman, J. Evading tumor evasion: Current concepts and perspectives of anti-angiogenic cancer therapy. Drug Resist. Updates 2010, 13, 16-28. [CrossRef] [PubMed]

43. Loboda, A.; Jozkowicz, A.; Dulak, J. HO-1/CO system in tumor growth, angiogenesis and metabolism-Targeting HO-1 as an anti-tumor therapy. Vascul. Pharmacol. 2015, 74, 11-22. [CrossRef] [PubMed]

44. Neyens, E.; Baeyens, J. A review of classic fenton's peroxidation as an advanced oxidation technique. J. Hazard. Mater. 2003, 98, 33-50. [CrossRef]

45. Was, H.; Dulak, J.; Jozkowicz, A. Heme oxygenase-1 in tumor biology and therapy. Curr. Drug Targets 2010, 11, 1551-1570. [CrossRef] [PubMed]

46. Poss, K.D.; Tonegawa, S. Reduced stress defense in heme oxygenase 1-deficient cells. Proc. Natl. Acad. Sci. USA 1997, 94, 10925-10930. [CrossRef] [PubMed] 
47. Lavrovsky, Y.; Schwartzman, M.L.; Levere, R.D.; Kappas, A.; Abraham, N.G. Identification of binding sites for transcription factors NF-kappa B and AP-2 in the promoter region of the human heme oxygenase 1 gene. Proc. Natl. Acad. Sci. USA 1994, 91, 5987-5991. [CrossRef] [PubMed]

48. Schmidt, A.; Bekeschus, S.; Jablonowski, H.; Barton, A.; Weltmann, K.D.; Wende, K. Role of ambient gas composition on cold physical plasma-elicited cell signaling in keratinocytes. Biophys. J. 2017, 112, 2397-2407. [CrossRef] [PubMed]

49. Bekeschus, S.; Schmidt, A.; Bethge, L.; Masur, K.; von Woedtke, T.; Hasse, S.; Wende, K. Redox stimulation of human THP-1 monocytes in response to cold physical plasma. Oxid. Med. Cell. Longev. 2016, 2016, 5910695. [CrossRef] [PubMed]

50. Lin, C.W.; Shen, S.C.; Hou, W.C.; Yang, L.Y.; Chen, Y.C. Heme oxygenase-1 inhibits breast cancer invasion via suppressing the expression of matrix metalloproteinase-9. Mol. Cancer Ther. 2008, 7, 1195-1206. [CrossRef] [PubMed]

51. Becker, J.C.; Fukui, H.; Imai, Y.; Sekikawa, A.; Kimura, T.; Yamagishi, H.; Yoshitake, N.; Pohle, T.; Domschke, W.; Fujimori, T. Colonic expression of heme oxygenase-1 is associated with a better long-term survival in patients with colorectal cancer. Scand. J. Gastroenterol. 2007, 42, 852-858. [CrossRef] [PubMed]

52. Ishikawa, T.; Yoshida, N.; Higashihara, H.; Inoue, M.; Uchiyama, K.; Takagi, T.; Handa, O.; Kokura, S.; Naito, Y.; Okanoue, T.; et al. Different effects of constitutive nitric oxide synthase and heme oxygenase on pulmonary or liver metastasis of colon cancer in mice. Clin. Exp. Metastasis 2003, 20, 445-450. [CrossRef] [PubMed]

53. Dey, S.; Sayers, C.M.; Verginadis, I.I.; Lehman, S.L.; Cheng, Y.; Cerniglia, G.J.; Tuttle, S.W.; Feldman, M.D.; Zhang, P.J.; Fuchs, S.Y.; et al. ATF4-dependent induction of heme oxygenase 1 prevents anoikis and promotes metastasis. J. Clin. Investig. 2015, 125, 2592-2608. [CrossRef] [PubMed]

54. Jozkowicz, A.; Was, H.; Dulak, J. Heme oxygenase-1 in tumors: Is it a false friend? Antioxid. Redox Signal. 2007, 9, 2099-2117. [CrossRef] [PubMed]

55. Chau, L.Y. Heme oxygenase-1: Emerging target of cancer therapy. J. Biomed. Sci. 2015, 22, 22. [CrossRef] [PubMed]

56. Thibodeau, B.J.; Geddes, T.J.; Fortier, L.E.; Ahmed, S.; Pruetz, B.L.; Wobb, J.; Chen, P.; Wilson, G.D.; Akervall, J.A. Gene expression characterization of HPV positive head and neck cancer to predict response to chemoradiation. Head Neck Pathol. 2015, 9, 345-353. [CrossRef] [PubMed]

57. Garg, A.D.; Galluzzi, L.; Apetoh, L.; Baert, T.; Birge, R.B.; Bravo-San Pedro, J.M.; Breckpot, K.; Brough, D.; Chaurio, R.; Cirone, M.; et al. Molecular and translational classifications of DAMPs in immunogenic cell death. Front. Immunol. 2015, 6, 588. [CrossRef] [PubMed]

58. Kepp, O.; Senovilla, L.; Vitale, I.; Vacchelli, E.; Adjemian, S.; Agostinis, P.; Apetoh, L.; Aranda, F.; Barnaba, V.; Bloy, N.; et al. Consensus guidelines for the detection of immunogenic cell death. Oncoimmunology 2014, 3, e955691. [CrossRef] [PubMed]

59. Galluzzi, L.; Buque, A.; Kepp, O.; Zitvogel, L.; Kroemer, G. Immunogenic cell death in cancer and infectious disease. Nat. Rev. Immunol. 2017, 17, 97-111. [CrossRef] [PubMed]

60. Bekeschus, S.; Mueller, A.; Miller, V.; Gaipl, U.; Weltmann, K.-D. Physical plasma elicits immunogenic cancer cell death and mitochondrial singlet oxygen. IEEE Trans. Radiat. Plasma Med. Sci. 2018, 2, 138-146. [CrossRef]

61. Lin, A.; Truong, B.; Fridman, G.; Fridman, A.A.; Miller, V. Immune cells enhance selectivity of nanosecond-pulsed dbd plasma against tumor cells. Plasma Med. 2017, 7, 85-96. [CrossRef]

62. Bekeschus, S.; Rodder, K.; Fregin, B.; Otto, O.; Lippert, M.; Weltmann, K.D.; Wende, K.; Schmidt, A.; Gandhirajan, R.K. Toxicity and immunogenicity in murine melanoma following exposure to physical plasma-derived oxidants. Oxid. Med. Cell. Longev. 2017, 2017, 4396467. [CrossRef] [PubMed]

63. Loboda, A.; Jazwa, A.; Wegiel, B.; Jozkowicz, A.; Dulak, J. Heme oxygenase-1-dependent and -independent regulation of angiogenic genes expression: Effect of cobalt protoporphyrin and cobalt chloride on VEGF and IL-8 synthesis in human microvascular endothelial cells. Cell. Mol. Biol. (Noisy-le-grand) 2005, 51, 347-355.

64. Yokoo, Y.; Kijima, A.; Ishii, Y.; Takasu, S.; Tsuchiya, T.; Umemura, T. Effects of NRF2 silencing on oxidative stress-associated intestinal carcinogenesis in mice. Cancer Med. 2016, 5, 1228-1238. [CrossRef] [PubMed]

65. Piantadosi, C.A.; Withers, C.M.; Bartz, R.R.; MacGarvey, N.C.; Fu, P.; Sweeney, T.E.; Welty-Wolf, K.E.; Suliman, H.B. Heme oxygenase-1 couples activation of mitochondrial biogenesis to anti-inflammatory cytokine expression. J. Biol. Chem. 2011, 286, 16374-16385. [CrossRef] [PubMed] 
66. Jablonowski, H.; von Woedtke, T. Research on plasma medicine-relevant plasma-liquid interaction: What happened in the past five years? Clin. Plasma Med. 2015, 3, 42-52. [CrossRef]

67. Jablonowski, H.; Santos Sousa, J.; Weltmann, K.D.; Wende, K.; Reuter, S. Quantification of the ozone and singlet delta oxygen produced in gas and liquid phases by a non-thermal atmospheric plasma with relevance for medical treatment. Sci. Rep. 2018, 8, 12195. [CrossRef] [PubMed]

68. Bekeschus, S.; Kolata, J.; Winterbourn, C.; Kramer, A.; Turner, R.; Weltmann, K.D.; Broker, B.; Masur, K. Hydrogen peroxide: A central player in physical plasma-induced oxidative stress in human blood cells. Free Radic. Res. 2014, 48, 542-549. [CrossRef] [PubMed]

69. Wende, K.; Williams, P.; Dalluge, J.; Gaens, W.V.; Aboubakr, H.; Bischof, J.; von Woedtke, T.; Goyal, S.M.; Weltmann, K.D.; Bogaerts, A.; et al. Identification of the biologically active liquid chemistry induced by a nonthermal atmospheric pressure plasma jet. Biointerphases 2015, 10, 029518. [CrossRef] [PubMed]

70. Bekeschus, S.; Schmidt, A.; Niessner, F.; Gerling, T.; Weltmann, K.D.; Wende, K. Basic research in plasma medicine-A throughput approach from liquids to cells. J. Vis. Exp. 2017, e56331. [CrossRef] [PubMed]

71. Bruggeman, P.J.; Kushner, M.J.; Locke, B.R.; Gardeniers, J.G.E.; Graham, W.G.; Graves, D.B.; Hofman-Caris, R.C.H.M.; Maric, D.; Reid, J.P.; Ceriani, E.; et al. Plasma-liquid interactions: A review and roadmap. Plasma Sources Sci. Technol. 2016, 25, 053002. [CrossRef]

72. Lackmann, J.W.; Wende, K.; Verlackt, C.; Golda, J.; Volzke, J.; Kogelheide, F.; Held, J.; Bekeschus, S.; Bogaerts, A.; Schulz-von der Gathen, V.; et al. Chemical fingerprints of cold physical plasmas-An experimental and computational study using cysteine as tracer compound. Sci. Rep. 2018, 8, 7736. [CrossRef] [PubMed]

73. Kansanen, E.; Kuosmanen, S.M.; Leinonen, H.; Levonen, A.L. The Keap1-nrf2 pathway: Mechanisms of activation and dysregulation in cancer. Redox Biol. 2013, 1, 45-49. [CrossRef] [PubMed]

74. Dinkova-Kostova, A.T.; Kostov, R.V.; Canning, P. Keap1, the cysteine-based mammalian intracellular sensor for electrophiles and oxidants. Arch. Biochem. Biophys. 2017, 617, 84-93. [CrossRef] [PubMed]

75. Schmidt, A.; Dietrich, S.; Steuer, A.; Weltmann, K.D.; von Woedtke, T.; Masur, K.; Wende, K. Non-thermal plasma activates human keratinocytes by stimulation of antioxidant and phase ii pathways. J. Biol. Chem. 2015, 290, 6731-6750. [CrossRef] [PubMed] 